\title{
Analisis Kemitraan Peternak Sapi Perah dengan KUD “Mitra Bhakti Makmur" Untuk Meningkatkan Perekonomian Masyarakat (Studi pada Desa Donowarih, Kecamatan Karangploso, Kabupaten Malang)
}

\author{
Dairy Farmers Partnership Analysis with KUD Mitra Bhakti Makmur \\ to Increase Community Economy (Case Study on Donowarih Village, \\ Karangploso Districts, Malang Regency)
}

\author{
Bayu Aji Prasetyo, Yoda Mahfudin Halim, Nora Galuh Candra A, \\ Zakariya Al Anshori, M. Anas Faradisa, Rahma Wulan S, Diah Retno S. F. \\ Fakultas Ilmu Administrasi Universitas Brawijaya \\ Jl. MT. Haryono 165 Kota Malang
}

DOI:https://doi.org/10.32781/cakrawala.v12i1.262

Received : 27 Januari 2018

Accepted : 9 Mei 2018

Published : 21 Mei 2018

\begin{abstract}
Abstrak:
Tujuan penelitian ini adalah mengetahui kemitraan peternak sapi perah dengan KUD "Mitra Bhakti Makmur" dalam meningkatkan ekonomi masyarakat peternak sapi perah, mengetahui faktor-faktor penghambat dan pendukung masyarakat peternak sapi perah untuk meningkatkan kemitraan dengan KUD “Mitra Bhakti Makmur" serta untuk mengetahui bentuk peningkatan ekonomi masyarakat peternak sapi perah setelah menjalin kemitraan dengan KUD Mitra Bhakti Makmur. Jenis penelitian yang digunakan adalah jenis penelitian deskriptif dengan pendekatan kualitatif kepada peternak sapi perah di desa Donowarih dan pengurus KUD Mitra Bhakti Makmur. Hasil penelitian ini menunjukkan bahwa bentuk kemitraan yang terjalin yakni complementary partnership yang merupakan bentuk mitra yang mendapat keuntungan dan pertambahan pengaruh melalui perhatian yang besar pada uang lingkup aktivitas yang tetap dan relatif terbatas, faktor pendorong yang mempengaruhi kemitraan yaitu faktor personal dan faktor oganiasaional. kemitraan yang terjalin antara peternak sapi perah dan KUD Mitra Bhakti Makmur memiliki hambatan yaitu hambatan personal dan hambatan organisasional.
\end{abstract}

Kata kunci: Kemitraan, KUD, Peternak Sapi Perah

Abstrack :

The purpose of this study was to determine the partnership between dairy farmers and KUD "Mitra Bhakti Makmur" to increase the economic of dairy farmers, determine barriers factors and proponent factors dairy farmers to increase the partnership with KUD "Mitra Bhakti Makmur" and to determine how form the increase of ecomonic dairy farmers after doing partnership with KUD "Mitra Bhakti Makmur". This type of research was a kind of descriptive research with a qualitative approach to dairy farmers in Donowarih village and staf of KUD "Mitra Bhakti Makmur". The results of this research showed that the type of partnership was complementary partnership which could defined a type of partnership which got adantages and increase of influence from great attention in money, static and limited activity, proponent factors of this reaserch was personal factor and organizational factors, partnership between diary farmers and KUD "Mitra Bhakti Makmur" had barriers factors like personal barriers and organizational barrier.

Keyword: Partneship, KUD, diary farmers

How to Cite:

Bayu Aji Prasetyo, Yoda Mahfudin Halim, Nora Galuh Candra A., Zakariya Al Anshori, M. Anas Faradisa, Rahma Wulan S, Diah Retno S. F.(2018). Analisis Kemitraan Peternak Sapi Perah dengan KUD Makmur" Untuk Meningkatkan Perekonomian Masyarakat (Studi pada Desa Donowarih, Kecamatan Karangploso, Kabupaten Malang). Cakrawala, 12(1), 13-23.

* Corresponding Author:

Nama : Zakariya Al Anshori

Email : zakariya009@gmail.com

Contact
(C) 2018 Badan Penelitian dan Pengembangan Provinsi Jawa Timur p-ISSN 1978-0354 | e-ISSN 2622-013X 


\section{Pendahuluan}

Kabupaten Malang merupakan salah satu kabupaten yang terletak di Provinsi Jawa Timur. Kabupaten Malang memiliki potensi peternakan yang cukup besar dengan produk unggulan antara lain sapi perah, sapi potong, ayam ras (petelur dan pedaging) dan kambing terutama Kambing PE (Peternakan Etawah). Produk unggulan peternakan tersebut berkembang dan terkonsentrasi dalam kawasan pengembangan sentra produksi antara lain sentra produksi sapi perah di Malang Timur, Barat dan Utara, kawasan sentra produksi sapi potong di daerah Malang Selatan dan kawasan sentra produksi ayam ras potong dan petelur di daerah Malang bagian tengah serta kawasan produksi Kambing PE di daerah Malang bagian Timur, Malang bagian Utara dan bagianSelatan (www.peternakan.malangkab.go.id).

Tabel 1 Produksi Susu Perah Kabupaten/Kota 2013

\begin{tabular}{lrrr}
\hline \multicolumn{1}{c}{ Kabupaten } & Sapi Perah & $\begin{array}{c}\text { Kambing } \\
\text { Perah }\end{array}$ & \multicolumn{1}{c}{ Jumlah } \\
\hline 01. Pacitan & 189059 & & 189059 \\
\hline 02. Ponorogo & 4176338 & 465324 & 4641662 \\
\hline 03.Trenggalek & 8900492 & 691057 & 9591549 \\
\hline 04. Tulungagung & 45720190 & 607248 & 46327438 \\
\hline 05. Blitar & 26012061 & & 26012061 \\
\hline 06. Kediri & 16529449 & 54732 & 16584181 \\
\hline 07. Malang & 127529424 & 1147721 & 128677145 \\
\hline 08. Lumajang & 7592674 & 116025 & 7708700 \\
\hline 09. Jember & 2760263 & & 2760263 \\
\hline 10. Banyuwangi & 1966197 & & 1966197 \\
\hline
\end{tabular}

Sumber:jatim.bps.go.id

Berdasarkan pada tabel 1.1 Peternakan sapi perah menjadi komoditas usaha yang cukup diminati masyarakat Kabupaten Malang, walaupun jumlah peminat usaha peternakan sapi perah tidak sebanyak peternakan unggas. Tabel berikut menunjukan besaran produksi susu sapi perah di kabupaten yang ada di Jawa Timur, salah satunya Kabupaten Malang. Hal ini tidak terlepas dari peran pemerintah yang mulai memberikan perhatian lebih kepada peternak sapi perah yang dibuktikan dengan peresmian program kemitraan usaha yang bertujuan menghubungkan para peternak sapi dengan Idustri Pengolahan Susu (IPS) oleh Menteri Perindustrian Airlanggar Hartanto sebagai upaya pemerataan kesejahteraan oleh pemerintah pusat (Tempo, 2017).
Program kemitraan usaha menurut Hafsah (2000) dapat diartikan sebagai suatu strategi bisnis yang dilakukan oleh dua pihak atau lebih dalam jangka waktu tertentu untuk meraih manfaat atau keuntungan bersama sesuai prinsip saling membutuhkan dan saling mengisi berdasarkan pada kesepakatan. Upaya untuk mewujudkan kemitraan telah dilakukan oleh berbagai pihak, antara lain dengan lahirnya undang-undang Nomor 9 tahun 1995 tentang usaha kecil dimana khusus mengetahui kemitraan usaha yang dituangkan dalam peraturan pemerintah (PP) No. 44 Tahun 1997, pemerintah melalui berbagai departemen ditugaskan untuk membina dan mendorong terlaksananya kemitraan usaha (Zakaria, 2015:11). Salah satu program kemitraan yang ada di Kabupaten Malang adalah kemitraan antara peternak sapi perah dengan Koperasi Unit Desa (KUD).

Salah satu wilayah yang menjalankan program kemitraan antara peternak sapi perah dengan KUD dan turut memberikan kontribusi terhadap produksi susu sapi yang ada di Kabupaten Malang adalah Desa Donowarih yang berada di Kecamatan Karangploso (karangploso.malangkab.go.id). Usaha ternak sapi perah memang merupakan salah satu usaha andalan sebagai sumber pendapatan rumah tangga di Desa Donowarih, karena sektor peternakan sapi perah ini dapat memberikan sumbangan yang cukup besar terhadap pendapatan masyarakat setempat. Berdasarkan hasil observasi narasumber menyebutkan bahwa sebelumnya basis sumber mata pecaharian pada Desa Donowarih berupa perkebunan apel, namun dikarenakan harga pestisida meningkat dan terlampau mahal para petani mulai beralih pada peternakan sapi perah. Awalnya pihak yang memfasilitasi hasil dari sapi perah hanya dari KUD "Karang Ploso", namun kemudian terdapat tawaran untuk bekerjasama dengan KUD “Mitra Bakti Makmur". Beberapa peternak mulai beralih untuk bekerjasama dengan KUD "Mitra Bakti Makmur", dikarenakan fasilitas, bentuk kerjasama dan harga susu yang diberikan oleh KUD "Mitra Bakti Mamur" dinilai lebih baik dibandingkan KUD "Karangploso. KUD "Mitra Bakti Makmur" memiliki peran sebagai pedagang perantara hasil susu dari para peternak sapi perah dan sekaligus menjadi agen dalam negosiasi harga, kualitas serta syarat- 
syarat pembelian susu lainnya sedangkan para peternak sapi perah berperan sebagai produsen susu dan penerima harga. Kemitraan masyarakat peternak sapi perah dengan KUD “Mitra Bahkti Makmur" dalam memberdayakan masyarakat peternak sapi perah untuk meningkatkan perekonomian masyarakat. Selain itu, ditujukan untuk mendeskripsikan, dan menganalisis faktor-faktor yang menghambat dan mendukung dalam masyarakat peternak sapi perah dan KUD "Mitra Bhakti Makmur" untuk meningkatkan perekonomian masyarakat peternak sapi perah.

\section{Tinjauan Pustaka}

\section{A. Kemitraan}

Kemitraan adalah suatu kerja sama formal antara individu-individu, kelompokkelompok atau oganisasi-organisasi untuk mencapai suatu tugas atau tujuan tertentu. Menurut Kamus Besar Bahasa Indonesia, arti kata mitra adalah teman, kawan kerja, rekan. Sementara kemitraan artinya perihal hubungan atau jalinan kerjasama sebagai mitra. Hafsah (2000) menjelaskan pengertian kemitraan adalah suatu strategi bisnis yang dilakukan oleh dua pihak atau lebih dalam jangka waktu tertentu untuk meraih keuntungan bersama dengan prinsip saling membutuhkan dan saling membesarkan. Keberhasilan kemitraan sangat ditentukan oleh adanya kepatuhan diantara yang bermitra dalam menjalanan etika bisnis.

B. Model-model Kemitraan dan Jenis Kemitraan

Menurut Levinger dan Muloy (2008), ada empat jenis atau tipe kemitraan yaitu:

a. Potential Partnership

Pada jenis kemitraan ini pelaku kemitraan saling peduli satu sama lain tetapi belum bekerja bersama secara lebih dekat.

b. Nascent Partneship

Pelaku kemitraan adalah partner dalam jenis kemitraan nascent partnehip tetapi efisiensi kemitraan tidak maksimal.

c. Complementary Partneship

Partner/mitra dalam jenis kemitraan complementay partnership mendapat keuntungan dan petambahan pengaruh melalui pehatian yang besar pada ruang lingkup aktivitas yang tetap dan relative tebatas seperti program delivery dan resource mobilization.

\section{d. Synergic Partnership}

Kemitraan jenis ini memberikan mitra keuntungan dan pengaruh dengan masalah pengembangan sistemik melalui penambahan ruang lingkup aktivitas baru sepertiadvokasi dan penelitian.

\section{Faktor Penghambat dan Pendorong} Kemitraan

Menurut Phillips El Ansori dalam Kuswidanti (2008), dalam peningkatan dampak kemitraan agar lebih baik dipengaruhi oleh faktor personal, adanya hambatan dari personal, faktor kekuasaan, faktor organisasional, hambatan dalam pengorganisasian, dan faktor lain. Faktor-faktor tesebut akan mempengaruhi kepuasan dan peningkatan keefektifan komitmen serta kebehasilan aktivitas atau kegiatan.

I. Faktor Pendukung

1. Faktor personal berupa kemampuan peternak sapi perah dalam berwirausaha, pengalaman peternak dalam merawat hewan ternak dan memerah susu serta kemampuan pengolahan hasil susu.

2. Faktor organisasional berupa misi dan program kesejahteraan anggota KUD. Mitra Bhakti Makmur, perluasan sektor mitra yang dimiliki KUD. Mitra Bhakti Makmur, serta mekanisme komunikasi dan pengambilan keputasan yang diterapkan KUD. Mitra Bhakti Makmur

II. Faktor Penghambat

1. Hambatan personal berupa tingkat kebosanan anggota lama dan siklus penerimaan dan pergantiankaryawan.

2. Hambatan organisasional berupa ketidaksesuaian visi antar mitra dengan stake holder dan pendanaan

3. Bentuk peningkatan perekonomian masyarakat peternak sapi perah setelah menjalin kemitraan dengan KUD. Mitra Bhakti Makmur

\section{Koperasi}

Latar belakang lahinya koperasi adalah keinginan dari para pendiri koperasi yang berusaha untuk membebaskan diri dari kesulitan ekonomi besama-sama. Robert Owen dalam Himpuni (2008) adalah pelopor lahirnya koperasi yang telah memberikan inspirasi tebentuknya kopeasi pertama kali 
di kora Rochdale pada tahun 1844. Secara harfiah kopeasi berarti bekerja sama. Koperasi terdiri atas dua kata yaitu co yang berarti bersama dan operation berarti bekerja, dengan kata lain koperasi merupakan suatu alat untuk memperbaiki kehidupan berdasarkan menolong diri sendiri (selfhelp) dan otoaktivitas dalam bentuk kerjasama. Koperasi pada asasnya bukan merupakan perkumpulan yang mencari keuntungan tetapi mencapai perbaikan hidup dan kesejahteraan anggotanya (Mahmud dalam Himpuni, 2008).

I. Koperasi Unit Desa

Pemikiran untuk meujudkan sistem ekonomi yang beasaskan kekeluargaan telah lama dicita-citakan oleh bangsa Indonesia untuk menggantikan secara fundamental sistem kapitalis yang dilaksanakan kolonis (Nasution, 1990). Pada tahun 1967 ditebitkan UU No.2/1967 tentang Pokok-Pokok Perkoperasian. Penjabaran UU No.12/1967 khususnya yang menyangkut pembangunan pedesaan dinyatakan dalam kebijaksanaan pemerintah melalui Instruksi Presiden Nomor 4 Tahun 1973 (Inpres No.4/1973) tentang Pengaturan dan Pembinaan Badan Usaha Unit Desa (BUUD). BUUD ini merupakan bibit dasar KUD.

Perubahan status BUUD menjadi KUD (Inpres 2/1978) menjadikan KUD bukan lagi sebagai kopeasi pertanian, tetapi menjadi koperasi serba usaha. Keanggotaan menjadi tebuka bagi semua warga desa yang bidang usahanya sangat beragam, yang berarti beragam pula kebutuhannya. Hal tersebut menjadikan KUD sulit menjadi organisasi ekonomi yang professional, karena profesionalisme memerlukan spesialisasi bukan generalisasi (Nasution,1990).

Menurut Dewi (2002) "koperasi susu merupakan jenis koperasi usaha tani, hal ini dapat dilihat dari usaha yang dilakukan profesi dari anggotanya. Koperasi susu beranggotakan para petani ternak sapi perah. Usaha yang dilakukan peternak sapi perah adalah menampung dan memasarkan air susu sapi anggota koperasi, disamping itu pula harus melakukan pembinaan tentang usaha peternakan sapi perah kepada para peternak. Berdasarkan uraian diatas dapat ditarik kesimpulan tentang pengertian koperasi susu yang menjadi objek penuls adalah merupakan jenis koperasi usaha tani yang beranggotakan para petani ternak sapi perah yang mengkhususkan dalam pengelolaan dan pembinaan usaha peternakan sapi perah sesuai dengan potensi ekonomi masyarakat pedesaan. Melalui koperasi diharapkan dapat menumbuhkanperanan dan tanggungjawab masyarakat pedesaan untuk berperan serta dan dapat menikmati hasil pembangunan guna meningkatkan taraf hidup.

\section{Metode Penelitian}

Jenis penelitian yang digunakan dalam penelitian ini adalah penelitian deskriptif dengan pendekatan kualitatif agar dapat menggambarkan dan menjelaskan secara terperinci tentang kemitraan yang terjadi antara peternak sapi perah dengan KUD. Mitra Bhakti Makmur. Lokasi penelitiannya adalah Desa Donowarih sedangkan situs dari penelitian ini adalah Dukuh Borogragal dan Koperasi Unit Desa Mitra Bhakti Makmur. Fokus penelitian dalam penelitian ini adalah:

1. Jenis kemitraan antara peternak sapi perah di Desa Donowarih dengan KUD Mitra Bhakti Makmur yang telah terjalin.

2. Usaha untuk meningkatkan kemitraan antara peternak sapi perah dengan KUD. Mitra Bhakti Makmur

Sumber data yang digunakan yaitu sumber primer berupa data hasil wawancara kepada ketua Koperasi Unit Desa (KUD) Mitra Bhakti Makmur, ketua kelompok peternak dan anggota kelompok peternak. Sumber Sekunder dari studi literatur, yaitu buku, jurnal, dan skripsi. Metode pengumpulan data dilakukan melalui observasi (pengamatan) ,wawancara, dokumentasi. Instrumen penelitian yaitu peneliti, interview guide (Pedoman Wawancara) dan perangkat penunjang berupa buku catatan dan alat tulis. Metode analisis data yang digunakan merupakan metode analisis Miles and Huberman. 


\section{Hasil dan Pembahasan}

\section{A. Analisis Data}

Bentuk Kemitraan yang dilakukan oleh KUD Mitra Bhakti Makmur dengan peternak sapi perah di desa Donowarih.

Kemitraan merupakan jalinan kerjasama sebagai mitra. Lebih lanjut kemitraan dijelaskan sebagai suatu strategi bisnis yang dilakukan oleh dua pihak atau lebih dalam jangka aktu tertentu untuk meraih keuntungan bersama dengan prinsip saling membutuhkan dan saling membesarkan (Hafsah,2000). Model-model kemitraan dikelompokkan menjadi empat jenis tipe kemitraan (Leinger dan Muloy (2008), sebagai berikut: a) Potential Partnership; b) Nascent Partnership; c) Complementary Partnership; d) Synergic Partnerhip.

Berdasarkan jenis model kemitraan yang telah disebutkan diatas. Kemitraan yang di laksanakan oleh KUD Mitra Bhakti Makmur adalah kemitraan complementary partnership. Complementary partnership menurut Levinger dan Muloy (2008) adalah partner atau mitra mendapat keuntungan dan pertambahan pengaruh melalui perhatian yang besar pada ruang lingkup aktivitas yang tetap dan relatif terbatas sepererti program delivery dan resources mobilization. Hal ini sama seperti yang dikemukakan oleh Bapak Soni ketua KUD Mitra Bhakti Makmur bahwa kemitraan yang mereka bentuknya adalah simbiosis mutualisme, saling membutuhkan antara peternak dan koperasi untuk mendistribusikan susunya. Koperasi memebutuhkan peternak untuk mendapatkan susu, sementara peternak membutuhkan koperasi untuk menjualnya. Maka dapat disimpulkan bahwa mereka saling membutuhkan dalam hal resources mobilization.

\section{B. Faktor-Faktor Pendukung dan Penghambat}

I. FaktorPendukung

a. Faktor Personal

Faktor Personal memiliki beberapa aspek seperti enterprise, experience, operasional understanding, benefit dan satisfaction resource allocation. Kemampuan peternak untuk berwirausaha diperlukan untuk mendukung terjadinya kemitraan dalam faktor personal selain berwirausaha pengalaman menjalankan bidang usaha, pengetahuan operasional serta cara mencari mitra yang menguntungkan juga diperlukan untuk mendukung kemitraan dalam faktor personal (Kuswidanti,2008). Hal tersebut berbeda dengan kemitraan yang terjalin antara KUD Mitra Bhakti Makmur dan peternak sapi perah di desa Donowarih. KUD Mitra Bhakti saat menentukan dan mencari mitra untuk bekerjasama hanya melihat pengalaman peternak dalam memelihara sapi namun tidak memperhatikan aspek kemampuan peternak dalam berwirausaha ataupun pemahaman peternak untuk memerah susu secara tepat. Hal ini diperkuat dengan pernyataan yang dikemukakan oleh Bapak Soni ketua KUD Mitra Bhakti Makmur bahwa syarat yang diberikan kepada peternak sapi perah untuk bermitra dengan KUD Mitra Bhakti Makmur adalah mereka diharuskan memiliki sapi serta mengikuti AD/ART yang dimiliki Koperasi.Sementara untuk menentukan ketua kelompok peternak dan ketua koperasi dilakukan melalui RAT (Rapat Anggota Tahunan) untuk menentukan pemimpin yang mampu menjalankan tugas dalam mengelola kemitraan dengan baik.

Aspek lain yang perlu diperhatikan dalam faktor personal adalah satisfaction resource allocation. Pendistribusian modal kepada secara tepat dapat mendukung keberlanjutan kemitraan serta terjalinnya kepercayaan antara KUD dan peternak sapi perah. Kemitraan yang terjalin antara KUD dan peternak sapi perah tersampaikan dengan baik dan tidak mengalami hambatan. Pernyataan ini diperkuat dengan pernyataan yang dibeikan oleh Bapak Soni selaku ketua KUD Mitra Bhakti bahwa pendistribusian modal yang berupa sapi perah unggulan yang diberikan oleh PT 
Indolakto akan disalurkan kepada peternak kemudian peternak akan merawat sapi buliran (Jenis sapi perah unggulan) dan mendapat penghasilan tiap sepuluh hari sesuai dengan jumlah susu yang dihasilkan oleh sapi yang mereka miliki. Para peternak juga akan mendapatkan keuntungan dari anak sapi yang lahir dari sapi bantuan tersebut.

Berdasarkan penjelasan diatas dapat disimpulkan bahwa aspek pendukung faktor personal diterapkan, namun kemitraan yang terjalin antara KUD dan peternak sapi di desa Donowarih mengabaikan kemampuan peternak sapi perah dalam hal berwirausaha.

b. Faktor Organisasional

Faktor Organisasional yang mendukung kemitraan adalah aspek rules and procedures, community representation, communiation quality and mechanism, dan decision making (Ansori dalam Kuswidanti,2008). Salah satu faktor pedukung yang penting adalah prosedur dan peraturan yan dibuat serta diterapkan dalam kemitraan. Peraturan yang sesuai serta memiliki tujuan baik untuk anggotanya dan tidak memberatkan salah satu pihak menjadi kunci kemitraan akan berjalan dengan baik. Peraturan yang diterapkan oleh KUD Mitra Bhakti Makmur sudah tepat dan tidak memberakan salah satu pihak. Hal ini dikemukakan oleh bapak Soni ketua KUD bahwa peraturan yang diterapkan diwujudkan dalam Misi yaitu kesejahteraan anggota koperasi dengan perinsip kekeluargaan. Peraturan yang dterapkan oleh KUD juga diwujudkan dalam programprogram yang meliputi: 1) Pelayanan kebutuhan pakan (polar, mineral, ampas tahu, kosentrat dan pakan hijau), 2) Bantuan kesehatan (penegahan dan pengobatan), dan 3) Penyediaan modal bibit sapi unggul. Program serta misi yang dibuat memberikan keuntungan bagi mitra yang menjalin kerjasama dengan KUD Mitra Bhakti Makmur.

Program serta misi yang sudah sesuai dan tepat akan lebih efektif apabila dapat disampaikan kepada mitra sehingga tidak terjadi kesalahpahaman. Komunikasi yang terjadi antara KUD Mitra Bhakti dan peternak sapi perah terjalin secara aktif dan tanpa hambatan. Komunikasi dilakukan secara lisan maupun tulisan melalui mekanismen musyawarah mufakat sehingga teguran maupun usulan yang ingin dikemukakan oleh peternak maupun pengurus KUD Mitra Bhakti Makmur dapat tersampaikan. Sementara komunikasi antar pegawai dilakukan sesuai dengan susunan stuktur organisasi tanpa adanya dominasi salah satu kelompok.

Hal yang sama diterapkan dalam pengambilan keputusan . Pengambilan keputusan yang dilakukan oleh KUD didasarkan pada musyarah mufakat dengan memperhatikan kepentingan bersama untuk pihak KUD Mitra Bhakti dan kelompok peternak sapi perah. Masalah-masalah yang dapat terselesaikan dengan jalan musyawarah mufakat seperti yang kemukakan oleh bapak Soni Ketua KUD Mitra Bhakti Makmur antara lain mengenai stabilitas harga susu sapi, pemebrian pinjaman modal bibit sapi dan perekrutan anggota baru. Berdasarkan penjelasan yang telah disebutkan diatas, faktor organisasional untuk mendukung adanya kemitraan diterapkan dengan baik oleh KUD Mitra Bhakti Makmur dan kelompok peternak sapi perah di desa Donowarih.

II. Faktor Penghambat

a. Hambatan Personal

Menurut Ansori dalam Kuswidanti (2008) hambatan dalam kemitraan antara lain priorities, expertise, availability, turnover dan interest: over long period. Cara anggota mitra memprioritaskan kegiatan kemitraan atau lebih mementingkan 
kepentingan pribadi dapat menjadi salah satu faktor penghambat kemitraan. Individu yang lebih memprioritaskan kehidupan pribadinya jelas akan mengganggu mitra yang lain untuk menjalin kerjasama. Hal ini tidak ditunjukkan oleh kemitraan yang terjalin antara KUD Mitra Bhakti Makmur dan peternak sapi perah di desa Donowarih. Aspek prioritas tidak menjadi hambatan dari kemitraan yang dilakukan oleh KUD Mitra Bhakti Makmur dan peternak sapi perah ini diperjelas dengan pernyataan yang diberikan oleh ketua KUD Mitra Bhakti Makmur bahwa anggota koperasi selalu hadir dalam setiap rapat dikarenakan rapat selalu diadakan atas persetujuan semua anggota serta jumlah anggota yang relati sedikit sehingga anggota selalu ikut berpartisipasi aktif. Berdasarkan pernyataan tersebut dapat disimpulkan bahwa anggota kelompok peternak sapi perah lebih memprioritaskan kemitraan yang mereka jalin daripada kepentingan priadi mereka.

Keaktifan anggota dalam mengemukakan pendapat atau keluhan penting agar tidak terjadi salah paham antar anggota. Anggota yang tidak mengemukakan pendapat dan cenderung pasif dapat menghambat kemitraan disebabkan ketidakpekaan anggota terhadap permasalah yang kemungkinan dihadapi dalam kerjasama yang mereka jalin. Keaktifan anggota kelompok peternak sapi perah dalam mengikuti rapat tercermin dari pendapat yang mereka kemukakan sesuai dengan pernyataan yang diberikan oleh bapak Soni selaku ketua KUD Mitra Bhakti Makmur.

Aspek selanjutnya yang dapat menghambat kemitraan yaitu Availability . Ketersedian fasilitas untuk rapat sangat diperlukan, apabila tidak disediakan maka akan menghambat kemitraan karena akan menghambat komunikasi secara langsung. Kemitraan yang dijalin antara KUD Mitra Bhakti Makmur memenuhi aspek availability sehingga tidak ditemukan hambatan atas ketersediaan fasilitas untuk rapat. Namun kegiatan rapat tidak rutin dilaksanakan yaitu hanya enam bulan sekali seperti yang dikemukakan oleh bapak Soni Ketua KUD Mitra Bhakti Makmur dan ketua kelompok ternak sapi perah.

Selanjutnya aspek yang dapat menghambat kemitraan dapat dilihat dari pergantian anggota, terlalu sering pergantian anggota atau tidak penah terjadi penggantian anggota kemitraan dapat menyebab hambatan. Pergantian anggota kemitraan yang terlalu sering dapat menyebabkan masalah seperti kurang memahaminya anggota baru terhadap $\mathrm{AD} / \mathrm{ART}$ koperasi serta program yang direncanakan dalam jangka panjang kemungkinan tidak dapat terlaksana tetapi apabila tidak ada penggantian anggota kemitraan akan menyebabkan kebosanan yang akan mengakibatkan penurunan kinerja anggota. Ini dialami oleh kemitraan yang dijalin antara KUD Mitra Bhakti dengan peternak sapi perah. Sejak tahun 1995 jarang ada pergantian anggota.

Aspek lain yang dapat menjadi hambatan adalah Interest : over a long priod. KUD harus menyiapkan program khusus atau kompensasi agar mitranya yaitu peternak sapi perah tetap menjalin kerjasama dengan KUD Mitra Bhakt. Namun hal ini tidak dilakukan oleh KUD Mitra Bhakti. Pemberian gaji disesuaikan dengan UMR karena KUD Mitra Bhakti termasuk dalam koperasi berskala kecil.

b. Hambatan Organisasional Hambatan organisasional dapat terjadi akibat adanya aspek competing priorities. Keinginan maupun visi yang diinginkan anggota tidak semua disetujui oleh para stakeholder hal ini 
dapat menghambat kemitraan secara organisasional karena kebutuhan yang diharapkan oleh anggota untuk dipenuhi tidak disetujui oleh stakeholder. Keinginan yang tidak disetujui oleh stakeholder tidak menjadi hambatan dalam kerjasama mereka karena KUD selalu memperhatikan keluhan peternak sapi perah. Hal ini dituturkan oleh ketua KUD Mitra Bhakti Makmur bahwa keinginan mitra tidak semua disetujui tetapi KUD selalu memperhatikan keluhan peternah. Keluhan yang jarang disetujui adalah keinginan peternak agar harga per liter susu mengalami kenaikan mengikuti fluktuasi pasar dan memberikan harga yang terus menerus tinggi". Aspek lain dalam hambatan organisasional adalah hambatan terkait dana. Hambatan dana tidak dirasakan oleh KUD Mitra Bhakti Makmur karena dana yang diperlukan selalu dalam keadaan yang tercukupi selain itu sistem yang dijalankan untuk mengelola dana sudah efekti dan efisien menurut pengurus KUD .

Berdasarkan pembahasan diatas dapat disimpulkan bahwa kemitraan yang dilakukan oleh KUD Mitra Bhakti dengan petenak sapi perah di desa Donowarih tidak mengalami hambatan secara organisasional.

1. Bentuk peningkatan perekonomian masyarakat peternak sapi perah setelah menjalin kemitraan dengan KUD. Mitra Bhakti Makmur adalah dengan dimilikinya pendapatan tetap tiap sepuluh hari yang diambil dari hasil perolahan susu masing masing peternak. Hal tersebut cukup meningkatkan perekonomian masyarakat peternak sapi perah karena masyarakat tersebut dulunya penghasilannya tidak tetap setelah menjalin kemitraan dengan KUD. Mitra Bhakti Makmur mereka bisa mendapatkan pendapatan tetap tiap sepuluh hari akan tetapi pendapatan yang diperoleh tersebut mereka nilai hanya cukup untuk kebutuhan makan saja belum kebutuhan lain-lain. Hal tersebut terjadi karena ketidaksesuaian harga yang ditetapkan oleh KUD. Mitra Bhakti Makmur sehingga biaya yang dikeluarkan oleh peternak untuk kebutuhan pakan, polar, mineral, ampas tahu, kosentrat dan pakan hijau seimbang dengan pendapatan dari hasil susu yang mereka dapatkan tiap sepuluh hari.

\section{Simpulan}

Bentuk kemitraan yang selama ini terjalin antara peternak sapi perah di Desa Donowarih dengan KUD Mitra Bhakti Makmur adalah complementary partnership yaitu bentuk partner atau mitra yang mendapat keuntungan dan pertambahan pengaruh melalui perhatian yang besar pada ruang lingkup aktivitas yang tetap dan relatif terbatas seperti program delivery dan resources mobilization. Pelaksanaan kemitraan antara peternak sapi perah di Desa Donowarih dengan KUD Mitra Bhakti Makmur dilakukan secara simbiosis mutualisme, yaitu kerjasama saling membutuhkan. Koperasi membutuhkan peternak untuk mendapatkan susu, sementara peternak membutuhkan koperasi untuk pendistribusiannya. Kemitraan antara peternak sapi perah di Desa Donowarih dengan KUD. Mitra Bhakti Makmur dipengaruhi oleh dua faktor pendorong yaitu 1) Faktor personal memiliki beberapa aspek seperti enterprise, experience, operasional understanding, benefit serta satisfaction resource allocation. Kemitraan yang dilaksanakan oleh KUD Mitra Bhakti Makmur tidak menganggap faktor enterprise (berwirusaha), operasional understanding pemahaman peternak untuk memerah susu dengan tepat dan benefit (keuntungan) dari peternak, untuk bermitra namun hanya berdasarkan experience (pengalaman) peternak dalam memelihara sapi sebelumnya serta kesediaan anggota untuk patuh kepada AD/ART yang dimiliki KUD Mitra Bhakti Makmur. Aspek yang mendorong kemitraan antara peternak sapi oerah dan KUD Mitra Bhakti Makmur karena satisfaction resource allocation (pendistribusian modal) yang tepat serta mengalokasikan dana yang ada secara tepat. 2) Faktor organisasional, faktor organisasional 
memiliki beberapa aspek antara lain rules and procedures, community representation, communication quality and mechanism, dan decision making. Kemitraan yang dijalin oleh KUD Mitra Bhakti Makmur dengan peternak sapi perah memiliki semua aspek tersebut. Peraturan yang diterapkan KUD telah sesuai tidak memberatkan salah satu pihak, program dan misi yang sesuai dan efektif, proses komunikasi yang aktif dan tanpa hambatan, serta proses pengambilan keputusan yang didasarkan pada musyawarah mufakat sehingga kemitraan yang mereka jalin selama ini tetap berjalan lancar. Kemitraan antara peternak sapi perah di Desa Donowarih dengan KUD. Mitra Bhakti Makmur juga tidak lepas dari beberapa faktor penghambat, adapun faktor penghambat, 1) Hambatan personal antara lain aspek prioritas, ketersediaan fasilitas untuk rapat, siklus pergantian anggota, dan kompensasi atas jasa yang diberikan oleh mitra usaha. Memang tidak semua faktor tersebut benar-benar menghambat hubungan kemitraan antara peternak sapi perah di Desa Donowarih dengan KUD. Mitra Bhakti Makmur ada beberapa faktor penghambat yang berhasil diatasi oleh KUD. Mitra Bhakti Makmur yaitu aspek prioritas dari seluruh anggota koperasi yang faktanya memang mengedepankan kepentingan bersama, akan tetapi ada beberapa faktor yang memang berpotensi menghambat hubungan kemitraan tersebut antara lain pergantian anggota yang jarang dilakukan oleh KUD. Mitra Bhakti Makmur sejak tahun 1955 berpotensi meningkatkan tingkat kejenuhan anggota sesuai dengan teori yang dikemukakan oleh Ansori dalam Kuswidanti (2008), kemudian tidak rutinnya rapat yang dilakukan oleh KUD. Mitra Bhakti Makmur juga memiliki potensi menurunkan kerekatan hubungan komunikasi dengan peternak sapi perah di Desa Dono Warih, meskipun fasilitas rapat di sana memadai. Hal terakhir dari faktor personal yang sangat berpotensi menghambat dari hubungan kemitraaan tersebut adalah tidak adanya kompensasi khusus yang diberikan kepada mitra usaha atas jasa yang telah mereka berikan. 2) Hambatan Organisasional, hambatan organisasional dapat terjadi akibat adanya competing priorities. Kebutuhan mitra yang tidak semuanya dipenuhi oleh stakeholder. Kebutuhan yang tidak disetujui oleh stakeholder pada kemitraan yang terjalin antara KUD Mitra Bhakti Makmur dengan peternak sapi perah adalah pemintaan untuk menaikkan harga susu sesuai fluktuasi pasar. Hal ini tidak menyebabkan permasalahan yang menyebabkan perpecahan pada kemitraan yang mereka jalin karena pihak KUD selalu memperhatikan keluhan peternak. Terakhir kesimpulan dari semua yang telah dijelaskan sebelumnya, kemitraan yang terjalin antara peternak sapi perah di Desa Donowarih dengan KUD. Mitra Bhakti cukup membantu peningkatan perekonomian masyarakat meskipun dengan adanya peningkatan tersebut tidak dapat memberikan surplus pendapatan bagi peternak sapiperah.

\section{Saran}

KUD. Mitra Bhakti Makmur melakukan beberapa hal untuk mengatasinya antara lain : KUD Mitra Bhakti Makmur memperbaiki siklus pergantian anggota dengan cara regenerasi pengurus KUD Mitra Bhakti Makmur, mengupayakan adanya rapat rutin dan memanfaatkan segala fasilitas penunjang yang ada secara maksimal, memberikan kompensasi khusus untuk setiap anggota yang telah memberikan jasa lebih pada KUD Mitra Bhakti Makmur, mempertahankan cara penyelesaian hambatan yang pernah dialami dan berhasil untuk diselesaikan. Peternak Sapi Perah desa Donowarih, Peternak sapi perah diharapkan lebih aktif dalam menyampaikan keluhan serta kebutuhan mereka. Peternak sapi perah diharapkan dapat lebih inovatif untuk mengolah susu secara mandiri dan mencoba untuk melakukan wirausaha. PT Indolakto, perusahaan Indolakto diharapkan lebih memperhatikan mitra mereka yaitu peterrnak sapi perah agar keuntungan yang diperoleh kedua belah pihak sepadan, perusahaan Indolakto diharapkan untuk tetap mempertahankan kemitraan yang sudah terjalin dengan peternak sapi perah serta meningkatkan kualitas kemitraan yang dimiliki, perusahaan Indolakto diharapkan membuat program khusus agar mitra peternak sapi perah yang menjalin kerjsama dengan pihak PT Indolakto dapat bertukar pengalaman dan memperoleh skill baru dalam hal peternakan. Pemerintah, pemerintah Desa maupun Kementrian Bumi Desa memberikan program pelatihan khusus kepada peternak sapi perah untuk menambah keahlian peternak agar dapat berwirausaha secara mandiri. 


\section{Daftar pustaka}

Badan Pusat Statistik Jawa Timur.2013. Produksi Susu Perah Kabupaten/Kota, (Online), (https://jatim.bps.go.id/linkTabelStatis/, diakses pada 25 Mei 2016)

Badan Pusat Statistik Kabupaten Malang. 2016. Populasi Ternak Menurut Jenis Ternak Di Kabupaten Malang, (Online), (https://Malangkab.bps.go.id/linkTabelStati s/view/id/556, diakses pada 25 Mei 2016)

Baswir, revrisond. 2014. Ekonomi Kerakyatan sebagai Sistem Indonesia. Dalam Muhammad Ridwan (Ed), Ekonomi kerakyatan (hlm 29-38). Jakarta Selatan: Lembaga Suluh Nusantara

Damayanti, Mia Nur. 2009. Kajian Pelaksanaan Kemitraan Dalam Meningkatkan Pendapatan Antara Petani Semangka di Kabupaten Kebumen Jawa Tengah dengan CV. Bimandiri. Bogor: IPB Press. hal.18.

Departemen Pendidikan dan Kebudyaan. 2002. Kamus Besar Bahasa Indonesia. Jakarta : Balai Pustaka

Dinas Kecamatan Karangploso Kabupaten Malang. Tanpa tahun. Desa Donowarih, (Online), (karangploso.malangkab.go.id, diakses pada 25 Mei 2016)

Dinas Peternakan dan Kesehatan Hewan Kabupaten Malang. Tanpa tahun. Potensi Peternakan Kabupaten Malang, (Online) (http://peternakan.malangkab.go.id/, diakses pada 25 Mei 2016)

Ditjen P2M \& PL. 2004. Pelatihan Manajemen P2L \& PL Terpadu Berbasis Wilayah Kabupaten/Kota Membina Kemitraan Berbasis Institusi. Depkes RI.

Dewi, Kartika Tribuana dkk. 2002. Kemitraan Peternak Sapi Perah Dengan Kud "Batu" Dalam Meningkatkan Ekonomi Masyarakat Peternak Sapi Perah. Jurnal Administrasi Publik(Jap), Vol. 1 No. $4 \mathrm{Hal}$ : 73-82
Himpuni, Okwan. 2008. Analisis Kinerja Koperasi Unit Desa (KUD) Sumber Alam Kecamatan Dramaga Kabupaten Bogor Provinsi Jawa Barat. Skripsi tidak diterbitkan. Bogor: Departemen Agribisnis Fakultas Ekonomi dan Manajemen IPB.

Kabupaten Malang. 2016. Selayang Pandang, ( $\mathrm{O}$ n 1 i $\mathrm{n}$ e ) , (http://www.malangkab.go.id/site/read/detai 1/79/selayang-pandang.html 10 Mei 2016, diakses pada 25 Mei 2016)

Kuswidanti. 2008. Gambaran Kemitraan Lintas Sektor dan Organisasi di Bidang Kesehatan Dalam Upaya Penanganan Flu Burung di Bidang Komunikasi Komite Nasional Flu Burung dan Pandemi Influenza (Komnas FBPI). Skripsi tidak diterbitkan. Depok: Jurusan Kesehatan Masyarakat, Fakultas Kesehatan Masyarakat UI.

Levinger, Beryl dan Jean Muloy. 2004. Kemitraan dan Model-Model Pemberdayaan. Terjemahan oleh Ambar Teguh Sulistiyani. 2008. Yogyakarta: Media

Muhammad Jafar Hafsah. 2000. Kemitraan Usaha. Jakarta: Pustaka Sinar Harapan.

Nasution, H. Muslimin. 1990. Keragaan Koperasi Unit Desa sebagai Organisasi Ekonomi Pedesaan. IPB Scientific Repository, ( $\mathrm{O}$ n 1 i $\mathrm{n}$ e ) , (http://repository.ipb.ac.id/handle/12345678 9/1482, diakses pada 24 Mei 2016)

Nasution, H. Muslimin. 2002. Jati Diri Koperasi. IPB Scientific Repository, (Online), (http://repository.ipb.ac.id/handle/12345678 9/1494, diakses pada 24 Mei 2016)

Sugiyono. 2011. Metode Kuantitatif Kualitatif. Bandung: Alfa Beta

Sugiyono. 2012. Metode Penelitian Kuantitatif Kualitatifdan RED. Bandung: Alfa Beta

Sugiyono. 2013. Metode Penelitian Menurut Sugiyono. Bandung: Alfa Beta 
Sugiyono. 2014. Metode Penelitian Kuantitatif Kualitatifdan RED. Bandung: Alfabeta.

Silalahi, Ulber.2009. Metode Penelitian Sosial. Bandung: PT. Refika Aditama

Tempo. Jumat, 5 Mei 2017. Kebijakan Kemitraan Peternak Sapi Perah dan Industri Disiapkan, (Online),(https://bisnis.tempo.co/read/news /2017/05/05/090872472/kebijakankemitraan-peternak-sapi-perah-danindustri-disiapkan, diakses pada $25 \mathrm{Mei}$ 2016)

Ulfie, Agustinus. 2013. Kearifan Lokal (Local wisdom) Budaya Ain Ni Ain Masyarakat Key sebagai Sumber Belajar Sejarah Lokal untuk Memperkokoh Kohesi Sosial Siswa. Tesis Sekolah Pasca Sarjana Universitas Pendidikan Indonesia. Jakarta.

Undang-undang Republik Indonesia No.5/1992 tentang Perkoperasian. 1992. Jakarta : Kementrian Perindustriaan
Undang-Undang Republik Indonesia No.17 Tahun 2008 tentang Usaha Mikro, Kecil dan Menengah. 2008. Jakarta : Kementrian Perindustriaan

Undang-undang Republik Indonesia No.20 Tahun 2008 tentang Usaha Mikro, Kecil, dan Menengah. 2008. Jakarta : Kementrian Perindustriaan

Undang-Undang Republik Indonesia No.25/1992 tentang Perkoperasian. 1992 Jakarta : Kementrian Perindustriaan

Wibisono, Yusuf. 2007. Membedah Konsep dan Aplikasi CSR. Gresik: Fascho Publishing.

Zakaria, Fauzan. 2015. Pola Kemitraan Agribisnis. Gorontalo: Ideas publishing. 